\title{
Women and Orientalism: 19th century Representations of the Harem by European female travellers and Ottoman women
}

Thisaranie Herath

The inaccessibility of the Ottoman harems to European males helped perpetuate the image of the harem as purely sexual in nature and contributed to imperialistic discourse that positioned the East as inferior to the West. It was only with the emergence of female travellers and artists that Europe was afforded a brief glimpse into the source of their fantasies; however, whether these accounts catered to or challenged the normative imperialist discourse of the day remains controversial. Emerging scholarship also highlights the way in which harem women themselves were able to control the depiction of their private spaces to suit their own needs, serving to highlight how nineteenth century depictions of the harem were a series of cross-cultural exchanges and negotiations between male Orientalists, female European travellers, and shrewd Ottoman women.

"Only women should go to Turkey - what can a man see in this jealous country?" bemoaned the influential French critic, Theophile Gautier in $1861 .{ }^{1}$ He was referring, of course, to the secluded world of the harem, where Islamic doctrine forbidding the interaction of non familial males and females veiled Ottoman women from the gaze of European male travellers. It was only with the emergence of female travellers and artists that Europe was afforded a brief glimpse into the source of their fantasies; however, whether these accounts catered to or challenged the normative imperialist discourse of the day remains controversial. Whilst traditional scholarship tends to highlight how female Europeans presented an alternative to male dominated Orientalism, newer research points to prevailing undercurrents of fantasy and exoticism in female works that perpetuated the image of the distant 'Other.' Instead, by deconstructing claims of a separate and united female discourse, historians are better able to understand the ways in which representations of the harem in the 19th century were heterogeneous products of cross-cultural exchange and negotiation between female European travellers and the Ottoman women who welcomed them into their home.

Though the term existed as a general reference for artistic and literary depictions of broadly 'Eastern' subjects during the nineteenth century, Orientalism as coined by the prominent scholar Edward Said in his 1978 book of the same name, came to mean something entirely different. ${ }^{2}$

\footnotetext{
${ }^{1}$ Reina Lewis, "'Only Women Should Go to Turkey': Henriette Browne and Women's Orientalism,” Third Text 7 (1993): 57.

2 Orientalism: depiction of the aspects of Eastern cultures (Middle Eastern, South Asian, East Asian) by Western writers, artists, and historians. In Edward Said's book, Orientalism came to mean the ways in which these depictions portrayed the East in increasingly patronizing and polarizing terms.
} 
Said's Orientalism stemmed from the divide between the Orient and the Occident, a largely imaginary line that was less about physical geography as it was a human construction of an Oriental realm that was the polar opposite to a similarly constructed 'West." ${ }^{3}$ The product of this worldview was a discourse that "conceptualised the Orient as feminine, erotic, exotic, and savage, allowing the West to accede to a position of superiority as Christian, civilized, and moral." Though the exact extent to which Oriental cultural production influenced Western colonialism is still debated, most historians acknowledge the ways in which many Western Orientalist artists and writers, either implicitly or explicitly, shaped colonial and imperial discourse by producing works that placed the East in a position of inferiority in relation to the West. Nowhere is this barbarization more evident than when one examines Western cultural depictions of Ottoman harems.

Ottoman harems, by Islamic law, were impenetrable to all but women and male relatives. The obsession with breaching this particular cultural barrier became one of the defining features of European interaction with the Middle East, leading to a rich production of visual art and textual narratives that imagined in vivid yet inaccurate detail, the forbidden mysteries of the harem. Said notes the highly sexualized role of women in Orientalist narratives, where they were the "[creatures] of a male power fantasy. They express unlimited sexuality, they are more or less stupid, and above all they are willing." The travel accounts of European males of the time were unified in their depiction of harem women simultaneously as objects of pity, deprived of liberty, but also possessing a "libidinous nature," and whose licentiousness was endorsed by their husbands and masters. ${ }^{6}$ These travel accounts also served as factual narratives upon which numerous artists based their paintings. Painters such as Jean-Léon Gérome centred much of their artwork around the allure of beautiful, nude odalisques, either lying languidly on a divan, baring all to the viewer's gaze, or engaged in overtly sexual scenes such as a lone dancer performing for an all-male audience in a state of undress and utter abandon. ${ }^{7}$ Some painters, like the British artist, John Frederick Lewis, were longtime residents in Ottoman cities, lending unchallenged veracity to their paintings despite having never crossed the threshold of a harem. ${ }^{8}$ In such a way, the lack of access to harems served only to further perpetuate erroneous stereotypes about the Orient which quickly became ingrained in the collective imagination of Europeans.

A vocal criticism of Said's theory of Orientalism has come from various postcolonial and feminist historians such as Sarah Mills and Reina Lewis, who point to the lack of insight into gender issues as evidence of Orientalism being only concerned with men's 'singular' experience

\footnotetext{
${ }^{3}$ Nancy Micklewright and Reina Lewis, introduction to Gender, Modernity, and Liberty, edited by Nancy Micklewright and Reina Lewis (London: I.B. Tauris \& Co Ltd, 2006), 3.

${ }^{4}$ Lewis, “'Only Women'," 54.

${ }^{5}$ Aimillia Mohd Ramli, "Contemporary criticism on the representation of female travellers of the Ottoman harem in the 19th century: A review," Intellectual Discourse 19 (2011): 265.

${ }^{6}$ Ramli, 266.

${ }^{7}$ Reina Lewis, "Women Orientalist Artists: Diversity, Ethnography, Interpretation," Women: A Cultural Review 6, no.1 (2008): 98.

${ }^{8}$ Mary Roberts, Intimate Outsiders: The Harem in Ottoman and Orientalist Art and Travel Literature (Durham: Duke University Press, 2007), 11.
} 
of the Orient. ${ }^{9}$ In her book, Rethinking Orientalism: Women, travel, and the Ottoman harem, Lewis claims that Orientalist discourse was challenged at the very outset of its inception by a "gendered counter-discourse" of female travel accounts, memoirs, and fictions. ${ }^{10}$ Indeed, as Aimillia Ramli notes, this revisionist stance of some historians led to the writings of European women to be presented as the "alternative to hegemonic imperial discourse," mainly due to a perceived lack of direct involvement in the "imperial project."

Women's travel writing in the nineteenth century was a particularly lucrative genre, and harem literature as a subset was in particular demand. Published by respectable publishing houses, these accounts often went on to be reprinted as second or even third editions - such was their success. ${ }^{12}$ With the advent of the Tanzimat reforms in 1839, Ottomans became more open to Western culture, demonstrating an increased willingness to invite female foreigners into the sanctuary of the harem. ${ }^{13}$ Coupled with the development of modern infrastructure, the nineteenth century saw a sharp increase in mass tourism: some included a visit to the harem in their holiday itinerary whilst others, frequently wives of embassy or military personnel, were able to forge more lasting connections with harem women. ${ }^{14}$ Western women outside of aristocratic circles began to travel and write about harems that were also outside elite society; they gained access as governesses, as missionaries, and through connections via male relatives working in a military or governmental capacity. ${ }^{15}$ Consequently, there emerged a diverse body of literature surrounding the harem to finally satisfy the fantasy created by male artists and writers who depicted a sensuous and alluring harem, for women - despite their restricted mobility in public places - enjoyed more privileged access to the private spaces of the Orient than any male traveller. However, as recent feminist scholars point out, this unique access may very well have been the reason European female Orientalists were able to challenge the prevalent male fantasies of harem life.

Historians such as Billie Melman and Reina Lewis argue that this newfound access lent itself well to ethnographic accounts of the harem, which reinterpreted the space first and foremost as a familial and social space. ${ }^{16}$ They point to accounts such as those by Julia Pardoe who exclaims "if, as we are all prone to believe, freedom be happiness, then are the Turkish women the happiest, for they are certainly the freest individuals in the Empire." ${ }^{17}$ She goes onto to describe how a Turkish woman is allowed free rein to express her thoughts and opinions by her husband, a stark contrast to the silent passiveness of harem women depicted in most male accounts. ${ }^{18}$

\footnotetext{
${ }^{9}$ Ramli, 264.

${ }^{10}$ Reina Lewis, Rethinking Orientalism Women, Travel and the Ottoman Harem (London: I.B. Tauris, 2004$)$, 1-2.

11 Ramli, 263.

12 Micklewright and Lewis, 3-4.

13 Roberts, 60.

${ }^{14}$ Ibid., 9.

${ }^{15}$ Micklewright and Lewis, 9.

${ }^{16}$ Roberts, 61.

17 Julia Pardoe, "The City of the Sultan and the Domestic Manners of the Turks in 1836," in Gender, Modernity,and Liberty, ed. Nancy Micklewright and Reina Lewis (London: I.B. Tauris, 2006), 71.

18 Ibid., 71.
} 
Contrary to the common misconception of a harem as always polygamous, where a single man ruled "listless women, passively waiting ...to meet their master's sexual needs," Pardoe states that being the husband of two wives was rare, and a wife would rather "half a dozen odalisques into her harem than a second wife," giving a glimpse into the complex hierarchy of power and authority that structured the harem. ${ }^{19}$ A similar challenge to the portraiture of male Orientalist artists is issued by Henriette Brown, whose 'gendered conditions of production' gave an alternative to the listless existence of harem women. ${ }^{20}$ In her painting Harem Interiors, she represents the harem primarily as a social space, where groups of fully clothed women actively engage with each other; in The Visit, she depicts the interaction between a mother and a child, a novelty as children rarely fit into the perceived model of constant yet passive sexual abandon. ${ }^{21}$ Here, the harem is presented as a "network of specific kin relations, an extended family," and a direct challenge to the traditional imagery of the harem as consisting of "murderous rivalries...or untold female perversions." 22

Because they were in the unique position of being the only Europeans allowed access to the inner homes of the Ottomans, the travel accounts of women were especially regarded as being authentic and authoritative. This gave them the chance to directly judge other writers' work in a similar vein: at the appearance of an unknown harem account in 1890 in the British journal The Nineteenth Century, British writer Lucy Garnett sought to enhance her own credibility by pointing out the inconsistencies in the account and proclaiming it to be a fake whose authoress could not possibly be a Muslim woman. ${ }^{23}$ Similarly, another British writer, Anne Jane Harvey, having already written on her travels in Spain, Damascus, and Lebanon, repeatedly cautions her readers on the potential unreliability of other Western travel accounts, whether it be due to the author's failure to understand the culture or the lack of opportunity to do so in a short sojourn. ${ }^{24}$ Interestingly, she also warns that "magnificent feasts and dinners do not give Europeans a better knowledge of Turkish homes than a dinner or ball at Buckingham Palace or the Tuiliers would give a Turk, respecting the nature of domestic life in England or France." 25 There were even a few who, empowered by their own experiences, felt confident enough to criticize the popular paintings of male artists: in an April 1717 letter, Lady Mary Montague describes her experience at the hammam, or traditional Turkish bath, and states that she "[wished] secretly that [painter, Charles Jervas] could have been there invisible. I fancy it would have very much improved his art to see so many fine women naked in different posture." ${ }^{26}$ In doing so, it appears that all three women, and indeed many others, were coming to realize the need for authentic portrayal of harem households, and their varying complexities present across different Ottoman classes.

${ }^{19}$ Pardoe, 71.

${ }^{20}$ Lewis, "Women Orientalist Artists," 94.

${ }^{21}$ Ibid., 94.

${ }^{22}$ Micklewright and Lewis, 17.

${ }^{23}$ Ibid., 6.

${ }^{24}$ Annie Jane Harvey, “Turkish Harems and Circassian Homes," in Gender, Modernity, and Liberty, ed. Nancy Micklewright and Reina Lewis, (London: I.B. Tauris, 2006), 101-102.

${ }^{25}$ Harvey, 103.

${ }^{26}$ Roberts, 69. 
Recent scholarship, however, call into question the extent to which the harem representations by European women can be held up as an alternative discourse to the Orientalist hegemony. Just as male European accounts were shaped by the Orientalist and Imperialist perceptions of the day, so too were female narratives; women writers understood that their representations of the Orient "never stood alone," but relied on a similar citational discourse of "circulation and repetition of Western knowledges about the Orient." ${ }^{, 7}$ The same women that re-envisioned the harem as a space of domesticity and family could in the same vein, emphasize the continuing 'Otherness' of Oriental women. With Pardoe, it is the "almost total absence of education among Turkish women...their limited range of ideas...quiet, careless, indolent happiness...[amusement] with trifles, careless of all save the passing hour; a woman in person, but a child at heart." ${ }^{28}$ Here, despite her previous positive portrayal of harem women, she infantilizes them in words mired with condescension, failing to realize the complex political nature of the harem and the crucial role women often played in state affairs. This ignorance is further highlighted when Annie Harvey speculates that:

The great bar to any real progress being made towards their due education and the enlargement of their minds, is the seclusion in which they live. Men and women are evidently not intended to live socially apart, for each deteriorates by separation. Men who live only with other men become rough, selfish, and coarse; whilst women, when entirely limited to the conversation of their own sex, grow indolent, narrow-minded, and scandal-loving. ${ }^{29}$

This statement echoes the European misconception present amongst both male and female members, that division and seclusion of space automatically translated to a lack of involvement in public life - in other words, total isolation. The Victorian society which formed their own biases and worldviews ordained the clear demarcation of public and private life into two separate spheres. ${ }^{30}$ Thus, seen through the lens of their own lived experiences, it seemed unfathomable to them that women cloistered away in a harem could exert even the smallest degree of influence outside the confines of their prison.

Just as they possessed preconceived notions of space and power, European women were unable to completely detach themselves from the exoticizing, sexualizing elements of Orientalist discourse. Contrary to what traditional scholarship initially indicated, female travellers did not completely dispense with the male fantasy of the harem; instead, they appropriated aspects of it to become equally as invested in the image of the harem as a place of mystery and intrigue. The

\footnotetext{
${ }^{27}$ Micklewright and Lewis, 3.

28 Pardoe, 71.

${ }^{29}$ Harvey, 104.

${ }^{30}$ Micklewright and Lewis, 19.
} 
trope of The Arabian Nights, so popular back in Europe, formed the foundation for the harem adventures of which these women imagined themselves to be the main protagonists, and harem women were cast either as beautiful but tragic victims or seductive and cunning femme fatales. ${ }^{31}$ After attending a soirée, Mary Herbert writes "the English ladies returned home, feeling the whole time as if they had been seeing a play acted from a scene in the "Arabian Nights," so difficult was it to realise that such a kind of existence was possible in the present century." 32 The account of Emilia Hornsby's visit to the harem of Riza Pasa in 1856 reads like a romance novel for its intrigue and tension; entering the harem with two friends who had never visited before, Hornsby indulges in erotic speculation: "Poor Madame de Souci became very nervous. 'I hope to goodness they won't undress us' she said, colouring up...'I was told that perhaps they would.' 'Never mind if they do,' said I, laughing...'they are such pretty creatures...it will be like being undressed by fairies." "33 She further speculates on the possibility of being taken into the harem as a concubine, and instead of being suitably horrified, she is intrigued, wondering whether the Pasa would be a good-looking master. ${ }^{34}$ In this way, the harem becomes an outlet for Hornsby to fantasize about forbidden desires, a temporary reprieve from the strict sexual regulations imposed upon women by Victorian morality. This descent into fantasy is catalyzed and heightened by the luxurious surroundings of the harem, which these women interpret as being in accordance with the descriptions of The Arabian Nights. ${ }^{35}$ Annie Jane Harvey writes that

the great height of these rooms, the brilliancy of the colouring, the lavish decoration, the shaded light, the sweet scent of the flowers, and the soft splashing of the fountains, make one feel on entering as if suddenly transported into the scenes of the old stories of childhood. As the fairy palaces of the Arabian Nights' are real, so must be their fairy owners,

further emphasizing how the way they perceived their Ottoman hosts were sometimes inseparable from the fantastical way they dreamt about their surroundings. ${ }^{36}$

Similarly, the intrusive male gaze of the European traveler finds its companion in the female search for beauty among the harem women. Whereas the male accounts had speculated upon the

\footnotetext{
31 Roberts, 63.

32 Ibid., 63.

33 Ibid., 64.

34 Ibid., 65.

35 The trope of the Arabian Nights was a common one in 19th century western literature. The 1885 publication of Sir Richard Burton's The Book of The Thousand Nights and a Night introduced Europe to a host of Eastern folk tales and stories that were originally compiled in Arabic during the Islamic Golden Age. These stories were often sexual in nature and described the palaces, peoples, and harems of the East in intriguing and extravagant terms. 36 Roberts, 66.
} 
abundance of beauty in the harem, the female accounts are far more critical but no less objectifying:

There was a remarkable want of beauty. With exception of the pretty Georgian, there was scarcely a good-looking woman in the room. The handsomest were, beyond all question, some coal-black Nubian slaves...one of them had the most beautiful figure we had ever seen. Tall, lithe, and supple, her small head exquisitely poised on a throat round and shapely as that of a statue... while her mouth, though full, had the waving lines of beauty, only seen in the Egyptian sphinx. ${ }^{37}$

In judging the harem women's beauty or lack thereof, female writers impose a different sort of gaze upon them; not overtly sexual, but intrusive, superficial and critical nonetheless. Of course, this flight of fantasy can only be sustained as long as the harems adhere in even the smallest ways to the scenes presented in The Arabian Nights. However, by the mid-nineteenth century, elite Ottoman harems were becoming increasingly modernized and along with it, the traditional furnishings and decor and other harem accoutrements were slowly vanishing. The accompanying disenchantment when harems do not adhere to preconceived notions is highlighted in Murray's 1854 guidebook by an anonymous woman traveller who warned travellers of "disappointment...when a spurious imitation of our own drawing rooms alone will be found behind those trelliced screens and lattice-work, which were supposed to conceal a whole world of a novel fashion." ${ }^{38}$

If European women were able to experience both fact and fantasy of the harem, presenting it simultaneously as a place of domestic harmony and of courtly intrigue, what role did Ottoman women play in either facilitating or resisting such an exchange? The answer is presented in the latter third of Mary Roberts' book, Intimate Outsiders: The Harem in Ottoman and Orientalist Art and Travel Literature. Roberts paints a picture of inquisitive women who share a similar curiosity to learn about the 'Other' - in this case, their European counterparts. By inviting foreign women into the domain of the harem, Ottoman women were able to exert considerable control over that which they presented to their visitors - a striking similarity to the way in which harem visits amongst elite women were traditionally used to foster inter-harem connections and power alliances. While Orientalist paintings depicted their female subjects in a voyeuristic fashion, European women could no longer gaze upon the Ottoman women unobserved. Entry into this inner sanctuary required both the loss of one's male travelling companions and one's anonymity, leaving the visitors feeling exposed and vulnerable, with the feeling of being watched by some

\footnotetext{
${ }^{37}$ Roberts, Intimate Outsiders., 67.

${ }^{38}$ Ibid., 78.
} 
"unlocatable gaze in the harem." 39 Many travellers recall feeling anxious or unsettled over this undefinable presence, marking an almost poetic reversal of the possessive Orientalist gaze. ${ }^{40}$

Some played into the part of traditional harem women by wearing their finest Ottoman costumes in front of their guests, despite evidence suggesting the increasing prevalence of the latest Parisian fashions among the elite. ${ }^{41}$ This suggests an awareness in harem women of their own stereotypical portrayals and a willingness to play a certain character in order to achieve their own ends. On the other hand, some Ottoman women insisted on showing off their latest European garments, intent upon dispelling archaic stereotypes by personifying the modernity sweeping the Empire at that time. ${ }^{42}$ In both cases, European women took note of the surprising curiosity they were subjected to: fascination over Western clothing and customs led to a barrage of questions that had Laura Starr remark, almost bemusedly: "We went to interview them, but my impression is that we were as much interviewed as they were." ${ }^{43}$ Here, European women were almost a curious spectacle, in much the same manner the Ottoman women were, hung on the drawing rooms of Paris or the art exhibitions of London. At the same time, some harems became increasingly reluctant to accept visitors, a reticence that may have stemmed from a combination of the saturation of female travellers to the Orient and a natural reluctance to present themselves as a tourist spectacle. ${ }^{44}$ In this instance, a refusal to engage with the 'Other' can be interpreted as Oriental women being the sole determinants of the time, place, and manner of their representation.

Still, visual culture itself became an important tool for Ottoman women in their quest to project an image of modernity and progress to the world: interestingly, there is mounting evidence that Ottoman women actually commissioned female European artists to paint portraitures of themselves. Sultan Abdulmecit's daughter, the Princess Fatma Sultan, enlisted the services of British artist Mary Adelaide Walker in the 1850s. Although Islamic law prohibits any representations of the figure, this was not strictly practiced within the elite circles; in fact, by the nineteenth-century, sultans were in the habit of commissioning portraits from visiting European artists and gifting them to foreign sovereigns abroad, a gesture that served to symbolize both diplomatic goodwill and the openness of the Empire to Western culture. ${ }^{45}$ While a portrait of the sultan's daughter could not be displayed to the public nor be gifted elsewhere for fear of violation of gendered seclusion, the function of the Princess's portrait essentially served a similar function in asserting her cultural receptivity and progressiveness - within the confines of the harem and its visitors. The very fact that many of the paintings commissioned by harem women

\footnotetext{
${ }^{39}$ Roberts, 83.

40 Ibid., 83.

${ }^{41}$ Micklewright and Lewis, introduction, 21.

${ }^{42}$ Roberts, Intimate Outsiders, 8.

43 Ibid., 86.

${ }^{44}$ Micklewright and Lewis, introduction, 9.

${ }^{45}$ Roberts, Intimate Outsiders, 114.
} 
are absent from public galleries or simply untraceable becomes a testament to the degree of control they exercised by being the ones to decide who their audience will be. ${ }^{46}$

The autonomy of Ottoman women when it comes to harem representations becomes clear when one examines the notes of Walker, who complains of her patron eschewing the traditional Ottoman costumes in favour of the latest Parisian fashions. "Such was the appearance of my imperial model: the ease, the grace, the dazzling magnificence of the East lost and dimmed by a painful striving after Western fashions," she laments. Her objections to the dress are met with unrelenting insistence that it was either "done according to [the princess's] wishes or not at all." 47 By doing so, Fatma maintains control of the way in which she is portrayed by the European artist, a stark departure from the passive helplessness that characterized earlier paintings of harem women who were subjected to the male gaze but were powerless to object. Instead, it is Walker who is frustrated by her client's refusal to conform to what her idea of a harem woman should be: passive, languid, at ease, and under her visual command. Instead, the princess is "very proud of her stiff, unbending waist, and insisted on being represented as sitting perfectly upright." what a harem woman should be, is thwarted by the agency of the woman in question herself, and emphasizes the disconnect between the Western view of the harem - and by extension of the Orient - as an unchanging, exotic, timeless place, and its reality as a complex and rapidly modernizing institution.

The emergence of gendered renditions of the harem and the Orient shed light upon several aspects of Ottoman culture that were obscured by the European male hunt for a sensual harem. However, when examining the continued threads of fantasy that is woven throughout the accounts of European female travellers, it becomes evident that despite a deeper, more intimate understanding of Ottoman culture, even Europeans with access to the realities of the harem were unable to fully shed their lingering Orientalist fantasies. In turn, these fantasies were challenged directly through harem visitation rituals or through the way in which Ottoman women controlled their own visual depiction. Thus, representations of the harem in the nineteenth century becomes not a separate discourses presenting hegemonic or counter-hegemonic views, but a series of cross-cultural exchanges and negotiations between male Orientalists, female European travellers, and shrewd Ottoman women.

\footnotetext{
${ }^{46}$ Roberts, Intimate Outsiders, 111.

${ }^{47}$ Ibid., 116.

${ }^{48}$ Ibid., 120.
} 


\section{Bibliography}

Harvey, Annie Jane. "Turkish Harems and Circassian Homes.” In Gender, Modernity, and Liberty, edited by Nancy Micklewright and Reina Lewis. 101-109. London: I.B. Tauris, 2006.

Lewis, Reina. "'Only Women Should Go to Turkey’ Henriette Browne and Women's Orientalism." Third Text 7, no. 22 (1993): 53-64.

Lewis, Reina. "Women Orientalist Artists: Diversity, Ethnography, Interpretation." Women: A Cultural Review 6, no. 1 (2008): 91-106.

Lewis, Reina. Rethinking Orientalism Women, Travel and the Ottoman Harem. London: I.B. Tauris, 2004.

Micklewright, Nancy and Reina Lewis. Introduction to Gender, Modernity, and Liberty, edited by Nancy Micklewright and Reina Lewis, 1-26. London: I.B. Tauris \& Co Ltd, 2006.

Pardoe, Julia. "The City of the Sultan and the Domestic Manners of the Turks in 1836." In Gender, Modernity, and Liberty, edited by Nancy Micklewright and Reina Lewis. 65-76. London: I.B. Tauris, 2006.

Ramli, Aimillia Mohd. "Contemporary criticism on the representation of female travellers of the Ottoman harem in the 19th century: A review," Intellectual Discourse 19 (2011): 263279.

Roberts, Mary. Intimate Outsiders: The Harem in Ottoman and Orientalist Art and Travel Literature. Durham: Duke University Press, 2007. 